\title{
Opium, Experimentation, and Alterity in France
}

\author{
E. C. Spary \\ Corpus Christi College, University of Cambridge, UK \\ Email: ecs12@cam.ac.uk
}

\begin{abstract}
The effects and dangers of opium were subject to intense scientific scrutiny and experimentation in Paris in the decades around 1700, as rival networks of healers contended for commercial advantage over the compound drugs that contained it. Opium, widely consumed in the Ottoman empire, became a subject of European scientific interest in an attempt to render it safe, agreeable, and beneficial for European bodies. Apothecaries sought to resurrect an ancient drug and infuse it with new life in the laboratory; physicians conducted chemical experiments upon it. Yet it was hard to reach agreement as to opium's harmful or beneficial effects; some aspects of its nature proved impossible to 'domesticate' in the same way as other exotic drugs like coffee or tea, or even cinchona. I argue that only by investigating the discrete networks which sold and experimented upon opium can the historian account for the ways in which this drug generated social, political, and financial capital for experimenters as it circulated throughout society.
\end{abstract}

One of the most difficult issues with which historians might engage is past experiences of consuming foods or drugs, a phenomenon at once deeply personal, yet at the same time structured and framed by how those drugs were appropriated and accounted for in the culture to which the consumer belongs. ${ }^{1}$ The term 'experience' should not here be understood as referring to an endeavour by social historians of early modern medicine in the 1980s and 1990 s to 'recapture lived experience'. ${ }^{2}$ Instead, this article begins with one of the rare instances when an early modern individual described the effects of taking an exotic drug. From this starting point, it explores how somatic individuality was related to a particular politics of experience that served to promote and make meaningful the consumed substance.

\footnotetext{
${ }^{1}$ Sean R. Silver, 'Locke's pineapple and the history of taste', Eighteenth Century, 49 (2008), pp. 43-65.

${ }^{2}$ Barbara Duden, The woman beneath the skin: a doctor's patients in eighteenth-century Germany (Cambridge, MA, 1991); Roy Porter, ed., Patients and practitioners: lay perceptions of medicine in preindustrial society (Cambridge, 1985).

(C) The Author(s), 2021. Published by Cambridge University Press. This is an Open Access article, distributed under the terms of the Creative Commons Attribution licence (http://creativecommons.org/licenses/by/4.0), which permits unrestricted re-use, distribution, and reproduction, provided the original article is properly cited.
} 
Such an approach affords an insight into what might be termed the 'pharmacological regime' of seventeenth-century France. By this I mean the ways in which the power of particular drugs - their effects upon individual bodies - were connected to debates about political power, commerce, or knowledge in a globalizing world. Current research is underscoring the central place of empire, global trade, and colonialism in European research into exotic drugs in the period around 1700, even if the French drugs trade has, until recently, received little attention compared with the English, Spanish, Portuguese, and Dutch cases. ${ }^{3}$ Exotic drugs are a valuable subject for historians interested in the connections between trade, materiality, and imperialism. Firstly, as material substances that had to be transported over long distances in order to be consumed, they left traces of their passage in archives and often generated an autonomous material culture (think coffee and coffee-pots). Secondly, drugs yoke together their places of origin and consumption, prompting debate over the significance of one location for the other, over the relationship between bodies and geographical space, and thus over how proximate agency (the act of consumption) is either affected by or affects very distant parts of the world. In a key sense, drugs showcase early modern preoccupations with the implications of otherness for European societies.

An obvious topos for such an enquiry, as newcomers to quotidian European consumption around 1700, are the exotic drinks of tea, coffee, and chocolate which have indeed received substantial historical attention. ${ }^{4}$ However, the main theme of this article is opium, a drug that, while exotic in the sense of being an import from outside Europe, did not become a direct focus of European imperial conquest at this time. Rather, it was linked with the Ottoman empire, a realm far more extensive and powerful than any European maritime empire around 1700. It thus connoted an empire of otherness: a referent to practices of consumption at once admired and despised, craved and spurned by affluent Europeans. Unlike coffee, opium never became

\footnotetext{
${ }^{3}$ Paula de Vos, 'The science of spices: empiricism and economic botany in the early Spanish empire', Journal of World History, 17 (2006), pp. 399-428; Teresa Huguet-Termes, 'New World materia medica in Spanish Renaissance medicine: from scholarly reception to practical impact', Medical History, 45 (2001), pp. 359-76; Patrick Wallis, 'Exotic drugs and English medicine: England's drug trade, c. 1550-c. 1800', Social History of Medicine, 25 (2012), pp. 20-46; José Luis Valverde, 'Research note on Spanish-American drug trade', Pharmacy in History, 30 (1988), pp. 27-32; Wouter Klein and Toine Pieters, 'The hidden history of a famous drug: tracing the medical and public acculturation of Peruvian bark in early modern western Europe (c. 1650-1720)', Journal of the History of Medicine and Allied Sciences, 71 (2016), pp. 400-21; Matthew Crawford, The Andean wonder drug: cinchona bark and imperial science in the Spanish Atlantic, 1630-1800 (Pittsburgh, PA, 2016). On the French case, see especially Samir Boumediene, La colonisation du savoir. Une histoire des plantes médicinales du 'Nouveau Monde' (1492-1750) (Paris, 2016); Justin Rivest, 'Testing drugs and attesting cures: pharmaceutical monopolies and military contracts in eighteenth-century France', Bulletin of the History of Medicine, 91 (2017), pp. 362-90.

${ }^{4}$ To mention only a few of the studies devoted to these exotic drugs in particular, see Markman Ellis, Richard Coulton, and Matthew Mauger, Empire of tea: the Asian leaf that conquered the world (London, 2015); Markman Ellis, The coffee-house: a cultural history (London, 2004); Marcy Norton, Sacred gifts, profane pleasures: a history of tobacco and chocolate in the Atlantic world (Ithaca, NY, 2008).
} 
the subject of colonial cultivation during the period, not least because the identity of the plant that produced it remained doubtful. ${ }^{5}$

Knowledge about opium, it will be argued, was similarly ambivalent. Well known and long present in European pharmacopoeias and medical practice, opium would never become 'domesticated' to the same extent as other exotic drugs like tobacco, pepper, sugar, or even cinchona. It remained stubbornly 'foreign' throughout the period under consideration, and the question is why this should be so. A positivist history might account for this difference with the claim that opium was inherently more potent than other drugs, and did not enter daily consumption for that reason. ${ }^{6}$ But such an argument rests upon the settlement of debates about the properties and effects of opium which, in the period around 1700, were still active. Rather than applying current scientific assessments of the corporeal effects of opium to past bodies, historians need to acknowledge that efficacy is itself historically contingent and relative. In particular, as this article will show, the potency of drugs may be tied to considerations of geopolitical potency - both literally, in the sense that the availability of a given material substance for consumers is contingent on trading relations with its place of origin, and figuratively, in the sense that the 'power' of drugs is related to the perceived relationship between the cultures of origin and consumption. Attempts to coax medicinal virtue out of opium operated on two levels, putting into question the capacity of experimentation to generate proof, and also mapping consumption onto French concerns about (religious or cultural) alterity in relation to empire.

I want to begin to illustrate these claims by invoking an early modern account of opium-eating that provokes a sense of sharp historical disjuncture in modern readers, in that it presents the drug as an aid to the preservation of health rather than an as addictive substance and a source of harm to the body. Its author, Moyse Charas, was an apothecary whose Protestant faith drove him on a European circuit from court to court before finally, under torture in a Spanish prison, he converted to Catholicism. ${ }^{7}$ He thereafter resumed a post

\footnotetext{
${ }^{5}$ On the beginnings of French colonial coffee cultivation, see E. C. Spary, Eating the Enlightenment: food and the sciences in Paris (Chicago, IL, and London, 2012), ch. 2; Albert Lougnon, L'T̂le Bourbon pendant la Régence. Desforges Boucher, les débuts du café (Paris, 1956). As late as the publication of Joseph Pitton de Tournefort's Voyage au Levant, in 1717, the botanical artist Claude Aubriet was only able to include a drawing of 'a very fine species of poppy which the Armenians call Aphion like common Opium; yet they take no Opium from it' (Relation d'un voyage du Levant fait par ordre du Roy (Paris, 1717), II, p. 277).

${ }^{6}$ See, for example, Martin Booth, Opium: a history (London, 1996). Extensive work on a later period by Virginia Berridge and others offers a methodologically sophisticated perspective upon the category of 'drugs' which informs my own; see especially Virginia Berridge, 'Dependence: historical concepts and constructs', in Griffith Edwards and Malcolm Lader, eds., The nature of drug dependence (Oxford, 1990), pp. 1-18.

${ }^{7}$ On Charas, see especially Bruno Bonnemain, 'Moyse Charas, un maître apothicaire et docteur en médecine emblématique de son époque (1619-1698)', Revue d'Histoire de la Pharmacie, 103 (2016), pp. 405-18; Fred W. Felix, 'Moyse Charas, maitre apothicaire et docteur en médecine', Revue d'Histoire de la Pharmacie, 90, no. 333 (2002), pp. 63-80; Maurice Bouvet, 'Les grandes familles pharmaceutiques: les Charas', Revue d'Histoire de la Pharmacie, 37, no. 124 (1949), pp. 453-63; Marie Phisalix, 'Moyse Charas et les vipères au Jardin du Roy', Archives du Muséum National d'Histoire
} 
at the Jardin du Roi in Paris, from which he had been expelled for his faith, and remained in Paris until his death in 1698. Some eighteen months before he died, Charas presented a paper at the Academy of Sciences in Paris on his personal experience of taking opium:

I think people will be very pleased to see me publish here, in good faith, what I have recently painstakingly observed on my own person, through the whole course of an illness of three months, from which I have recovered thanks to God, which principally consisted of a great reduction in strength and mental exhaustion, and of frequent severe episodes of sweating followed by horrible itching, with no pain in any individual part of my body. From the start, I foresaw that this illness which I was experiencing at a very advanced age could only be prolonged ... I thought it appropriate to take a grain of Opium Extract, as I did regularly every day at no fixed time ... my conviction that this Extract was sustaining my strength, made me punctilious about taking a grain a day. Its most noticeable effect was that of giving me a great inner tranquillity, with no drowsiness. ${ }^{8}$

Charas then proceeded to report on opium's other beneficial effects at some length, in particular its capacity to evacuate corrupt humours through his bowels and via perspiration. This extended self-accounting was characterized as a 'sincere recital of the extraordinary effects that Opium Extract has recently had upon me'. ${ }^{9}$ In other words, Charas's account of embodied experience possessed not only a medicoscientific goal - as a recital of natural facts before a company of savants - but also a theological one, as a genre of testimony

Naturelle, 6th ser., 12 (1935), pp. 469-72; Paul Cap, Études biographiques pour servir à l'histoire des sciences, 1st ser.: Chimistes - naturalistes (Paris, 1857), p. 117.

${ }^{8}$ Archives de l'Académie des Sciences, Paris, procès-verbaux (9 Sept. 1696), 'Nouvelles obseruations sur l'Opium par Charas', fos. 194v-195r: 'ie crois qu'on sera bien aise, que ie publie icy de bonne foy ce que i'ay depuis peu Soigneusement obserué sur ma persone, pendant tout le cours d'une maladie de trois mois, dont ie releue graces a Dieu, qui consistoit principalement en un grand abatement de forces et épuisement d'Esprit, et en de grandes et frequentes sueurs universelles suiuies d'horribles demangeaisons, sans aucune soufrances particulieres d'aucune partie de mon corps. Je préuis dés le commencement que cette maladie, m'ariuant en un Age fort auancé ne pouuoit estre que longue ... ie crus a propos de prendre, comme ie le fis reglément tous les jours sans aucune heure limitée, un grain d'Extrait d'Opium ... la persuasion où i'estois que cet Extrait soutenoit mes forces, en fortifiant la nature, me rendit ponctuel a en prendre un grain tous les jours. Son Efet le plus sensible estoit de me donner une grande tranquilité au dedans, sans aucun assoupissement.' This document is transcribed and briefly discussed in Claire Salomon-Bayet, 'Opiologia, imposture et célébration de l'opium', Revue d'Histoire des Sciences, 25 (1972), pp. 125-50.

${ }^{9}$ Archives de l'Académie des Sciences, Paris, procès-verbaux (9 Sept. 1696), fo. 196v: 'Le sincere recit des éfets extraordinaires, que l'Extrait d'Opium, vient de produire sur moy'. A copy of the talk in Charas's own hand is in his dossier biographique in this same archive. John Martin's argument that sincerity was a Renaissance invention particularly associated with Protestantism suggests that Charas's relationship with opium had links to his confessional struggles (John Martin, 'Inventing sincerity, refashioning prudence: the discovery of the individual in Renaissance Europe', American Historical Review, 102 (1997), pp. 1309-42, esp. p. 1331). As Valentina Pugliano, 'Pharmacy, testing, and the language of truth in Renaissance Venice', Bulletin of the History of Medicine, 91 (2017), pp. 233-73, shows, the term was used by earlier apothecaries in similar circumstances. 
or confession. Besides these twin aims, it will become clear that this selfnarration had commercial goals. Charas first entered the French crown's orbit in the 1650s as the owner of a successful pharmacy in the town of Orange, near Usèz, his place of birth. It was almost certainly under royal protection that he moved to Paris in 1659, settling in the rue des Boucheries and rapidly rising within the guild of Parisian apothecaries and grocers. While always anchored in the merchant milieu, he also laid claim to scholarly status; yet his place in the Republic of Letters would never be as secure as that of a man of the liberal professions.

That his auto-experimentation with opium was a self-reflexive contribution to medical knowledge is something Charas had made very clear in earlier descriptions of his opium consumption, in his well-known treatise Histoire natvrelle des animavx (1668) and his even better-known pharmacopoeia, the Pharmacopée royale galenique et chymique (1676). These accounts were evidently closely read, for they were quoted by several peers. ${ }^{10}$ Charas described his trials as a public service to correct misapprehensions: "the absence of close knowledge of opium, and the fear of making a mistake, has led some people to abstain from it and believe its use to be dangerous'. As a drug, opium was therefore to be saved for the task of healing - which was also God's intention for the plant - through auto-experimentation. Charas noted how 'the surprising effects of Opium ... have always occupied the minds of many curious people'. 'We could have been,' he told his fellow academicians, 'and we might yet be more instructed about it, if a number of people were to be as robust, curious and determined as I was.' However, he warned that the variety of complexions, diseases, and other circumstances meant that opium's effects upon bodies were very variable. ${ }^{11}$

In this exhortation to the learned company (whose deeds were the subject of regular newspaper reports), Charas thus classed himself among a privileged number of scholars who coupled strengths of body and mind, curiosity with constitutional robustness; who were able to auto-experiment with opium and gauge its effects upon the human body in a scientifically valid way; and whose reports were worthy of trust. He presented this experimentation as a courageous endeavour undertaken for the twin purposes of improving natural

\footnotetext{
${ }^{10}$ Moyse Charas, Histoire natvrelle des animavx, des plantes, \& des mineraux qui entrent dans la composition de la theriaque d'Andromachus. Dispensee et achevee publiquement à Paris ... (Paris, 1668), p. 86; Moyse Charas, Pharmacopée royale galenique et chymique (Paris, 1676), pp. 725-8. For discussion of Charas's accounts of drug-taking, see Journal des Sçavans, 10 Dec. 1668, pp. 136-9; Dictionnaire universel françois \& latin (2 vols., Trévoux, 1704), II, s.v. 'Opium'; [Henry Rouvière], Memoire en forme de factum, pour l'instruction de messieurs les juges, en l'instance pendante au criminel, \& pour servir de réponse justificative au second libelle injurieux \& diffamatoire de Monsieur Biet, en datte du 30 mars 1705 (n.p., 1705?), p. 24.

${ }^{11}$ Archives de l'Académie des Sciences, Paris, procès-verbaux (9 Sept. 1696), fo. 194, 'le défaut d'une jntime connoissance de l'Opium, et la crainte de s'y tromper, [qui] ait porté quelques uns a s'en abstenir et a en croire l'Vsage dangereux'; 'Les effets surprenans de l'Opium ... ont occupé de tout temps l'esprit de plusieurs curieux'; 'L'on eut pû, et l'on pouroit encore en estre plus jnstruit s'il se trouuoit quelque nombre de persones robustes, aussi curieuses et déterminées que ie le fus.'
} 
knowledge and assuaging public fear of a useful drug. It is rare to find records of auto-experimentation that offer quite so much detail on corporeal experience. While early modern diaries and letters allow us to grasp how ubiquitous auto-experimentation on drugs in fact was, Charas's enterprise appears to have gone somewhat further, and to have prioritized embodied knowledge as well as the (divine) purposes it served - or, rather, to have conferred a moral as well as an evidential role upon corporeal auto-experimentation. ${ }^{12}$

Although it is practically certain that Charas, like his fellow curious enquirers around Europe, auto-experimented on a wide range of other substances, including cinchona, little of his surviving oeuvre suggests that his other experiments possessed quite the importance of those conducted on two medicinal materials in particular, opium and viper venom, to which he returned throughout his life as an experimenter and scholar. Charas's claims about the first of these two substances might seem disconcerting to a modern reader - or, rather, that reader might be inclined to reframe his opium-eating as an example of addiction, implicitly replacing the drug within the category of dangerous or intoxicating materials. Yet the concept of addiction was not one which Charas himself would have recognized. ${ }^{13}$ A foodstuff or drug, he argued, might be dangerous to an inexperienced body, but not to a practised one. It was precisely for this reason, in his view, that 'robust' investigators of nature should all be taking opium, in order to gauge its effects and to reach agreement upon them. Only thus could the drug's providential purpose be fully understood by the light of reason.

Nor was Charas the only scientific and medical advocate for opium in early modern France. In 1726, the Paris medical faculty physician Philippe Hecquet would scoff at the notion that a drug like opium, taken so extensively throughout 'the vast empires of Persia, Turkey, the Indies, Egypt and beyond to Europe', could possibly be viewed as a poison. From the fact that 4,000 pounds of it were imported annually from Smyrna to Marseille, Hecquet argued, 'doesn't it become evident how astonishing the consumption of opium is? Could all the nations in the world possibly be conspiring in their own destruction, by cooperating to poison themselves? ${ }^{14}$

\footnotetext{
${ }^{12}$ For example, diaries and letters of Fellows of London's Royal Society, such as Robert Hooke, Robert Boyle, and John Locke, attest to their trialling of a range of new substances. See, e.g., Lotte Mulligan, 'Self-scrutiny and the study of nature: Robert Hooke's diary as natural history', Journal of British Studies, 35 (1996), pp. 311-42; Michelle DiMeo, 'Communicating medical recipes: Robert Boyle's genre and rhetorical strategies for print', in Howard Marchitello and Evelyn Tribble, eds., The Palgrave handbook of early modern literature and science (London, 2017), pp. 209-28; Esmond de Beer, ed., The correspondence of John Locke (Oxford, 1976-89), passim.

${ }^{13}$ The work of Virginia Berridge for the British case shows, similarly, that consensus about opium as a harmful substance arose only in the nineteenth century and not before: see Virginia Berridge, 'Victorian opium eating: responses to opiate use in nineteenth-century England', Victorian Studies, 21 (1977-8), pp. 437-61.

${ }^{14}$ Philippe Hecquet, Reflexions sur l'usage de l'opium, des calmants, et des narcotiques, pour la guerison des maladies. En forme de lettre (Paris, 1726), pp. 69, 71: 'les vastes Empires de Perse, de Turquie, aux Indes, en Egypte, \& delà en Europe'; 'ne vient-il point évident que la consommation de l'Opium est étonnante? Seroit-ce donc que toutes les Nations du monde auroient toutes conspiré leur propre perte, en se concertant ensemble pour s'empoisonner elles-mêmes.' Andreas-Holger Maehle, Drugs
} 
This last question - whether opium was a poison, and how its effects upon the body could be managed - preoccupied many experimenters in the decades around 1700. Not all were as optimistic about the drug as Charas or Hecquet. ${ }^{15}$ Many authors used opium to underline the geographical, cultural, and corporeal distance separating East and West. In a note on Lucretius's On the nature of things, Jacques Parrain des Coutures, a Norman military nobleman turned Republican of Letters, remarked: 'Here opium is a poison, in the Indies they take it without danger, to make themselves braver. ${ }^{16}$ Others, such as Nicolas Venette, a doctor in La Rochelle who had trained in Paris, rehearsed the truism that opium did not affect European and Turkish bodies in the same way, sometimes with disappointing results:

Europeans do not experience the same effects from the use of narcotics as Asians and Africans. Custom makes these drugs produce different effects in those who use them, and here we only observe tranquillity of the soul, and pleasure and itching of the body, rather than the turmoil of love to be seen among other peoples. ${ }^{17}$

The experience of a drug's corporeal and moral effects was highly geographically and culturally localized, following the irresistible spatial logic of early modern Hippocratic medicine, in which habit and climatic circumstance formed characters and virtues in all living bodies - plants as well as people. ${ }^{18}$ Yet the effects of 'intoxicants' and drugs are precisely what modern historians have often implicitly taken as identical between cultures, and therefore in no need of historical investigation. ${ }^{19}$

on trial: experimental pharmacology and therapeutic innovation in the eighteenth century (Amsterdam, 1999), p. 129, notes: 'Though well known as a powerful substance since antiquity, opium became a very widely used remedy in the West only in the seventeenth century.'

${ }^{15}$ For an overview, see Andreas-Holger Maehle, 'Pharmacological experimentation with opium in the eighteenth century', in Roy Porter and Mikuláš Teich, eds., Drugs and narcotics in history (Cambridge, 1995), pp. 52-76; Maehle, Drugs on trial, ch. 3.

${ }^{16}$ Jacques Parrain des Coutures, ed. and trans., Lucrece, de la nature des choses; avec des remarques sur les endroits les plus difficiles. Traduction nouvelle (2 vols., Lyon, 1695), II, pp. 493-4: 'L'opium est icy un poison, dans les Indes ils en prennent sans danger, pour se rendre plus vaillans.'

${ }^{17}$ Nicolas Venette, De la generation de l'homme, ou tableau de l'amour conjugal. Divisé en quatre parties (Cologne, 1703), p. 224: 'les Européens ne ressentent pas les mesmes effets de l'usage de ces Narcotiques, que font les Asiatiques \& les Africains. La coûtume fait que ces drogues produisent des effets differens dans ceux qui en usent, \& nous n'observons chez nous que la tranquilité de l'ame, le plaisir \& la démangeaison du corps, au lieu des égaremens amoureux qui se remarquent chez les autres.' Quite possibly Venette was specifically referencing Charas here, who also mentioned opium's aphrodisiac properties (Charas, Histoire natvrelle, p. 89).

${ }^{18}$ Andrew Wear, 'Place, health, and disease: the airs, waters, places tradition in early modern England and North America', Journal of Medieval and Early Modern Studies, 38 (2008), pp. 443-65; Genevieve Miller, “'Airs, waters and places” in history', Journal of the History of Medicine and Allied Sciences, 17 (1962), pp. 129-40.

${ }^{19}$ As Michael Stolberg, 'Der gesunde Leib: zur Geschichtlichkeit frühneuzeitlicher Körpererfahrung', Historische Zeitschrift, 31 (2001), pp. 37-57, argues, histories of medicine have traditionally treated the body 'fast ausschließlich als Gegenstand medizinischer Forschung und therapeutischer Inventionen' (p. 37). I would add to his call for attention to bodily 'experience' 
Opium was a drug uniquely tied to particular geopolitical relations between Ottomans and Europeans that changed over both space and time. Its ambivalent nature was central to the meanings attributed to it by French authors and consumers as royal policy towards the Ottomans developed over the course of Louis XIV's reign. In 1662, while the king was still supporting Habsburg efforts to recoup territories from Ottoman rule, the royal historiographer François Eudes de Mezeray published a new edition of the sixteenth-century geographer Nicolas de Nicolay's history of the Turks, including Nicolay's plates of Ottoman dress, concocted from a combination of antique coins and travel narratives. The plate 'Les Yvrognes' represented cruel Turks, 'full of rage and fury ( pleins de rage \& de furie)', who fought for pleasure and entertainment, losing 'all reason and judgement (toute raison \& iugement)'. This was largely a consequence, according to the caption, of Turkish consumption of sherbet, an opiumcontaining drink used by the peoples of the Levant to purge themselves of the melancholic humour and give themselves courage for battle: 'Having taken just one dram of this opium, they are so troubled and alienated in their minds that they can only walk unsteadily, and talk in frightful cries and howls. ${ }^{20}$ French relations with the Ottoman empire during the $1660 \mathrm{~s}$ explain why the interest of readers and consumers in Ottoman drugs, including opium-long a part of European healing traditions, featuring in both Galenic drugs and the newer Paracelsian medicine-was reignited during this same decade. ${ }^{21}$

Although the king's relations with the Ottomans thawed from the 1670 s onwards, this Renaissance trope of the Turk drunk on opium endured as a theme of seventeenth-century medical literature. The perceived violence of Turks carried over into discussions of the drug. As Jean Bernier, household physician to the duc d'Orléans, remarked in 1689, medical writers earlier that century had viewed opium, along with hellebore and mercury, as 'monsters and wild beasts that they did not know how to tame and domesticate.'. Opium, accordingly, had a bad reputation in French literate culture as a drug

the need to recognize the agency and opacity of the body that in the early modern period rendered replication of experience an impossibility.

${ }^{20}$ Nicolas de Nicolay, 'Plvsievrs descriptions des accovstremens, tant des magistrats et officiers de la Porte de l'Emperevr des Tvrcs, que des peuples assujectis à son Empire', in François Eudes de Mezeray, Histoire generale des Tvrcs, contenant l'Histoire de Chalcondyle (2 vols., Paris, 1662), II, pl. 18: 'Duquel Opium ayans pris enuiron vne dragme seulement, ils sont tellement troublez \& alienez de leur esprit, qu'ils ne peuuent marcher que tout chancelans, ny parler qu'auec des cris \& hurlemens espouuentables.' On French views of the Turks and Franco-Ottoman relations, see especially Nicholas Dew, Orientalism in Louis XIV's France (Oxford, 2009); Levent Y1lmaz, Le temps moderne. Variations sur les anciens et les contemporains (Paris, 2004), pp. 152-6; Kenneth Setton, Venice, Austria, and the Turks in the seventeenth century (Philadelphia, PA, 1991).

${ }^{21}$ Henry E. Sigerist, 'Laudanum in the works of Paracelsus', Bulletin of the History of Medicine, 9 (1941), pp. 530-44; Richard Davenport-Hines, The pursuit of oblivion: a social history of drugs (London, 2002), ch. 1.

${ }^{22}$ Jean Bernier, Essais de medecine où il est traité de l'histoire de la medecine et des medecins (Paris, 1689), p. 447: 'des monstres \& des bêtes feroces, qu'ils ne sçavoient pas addoucir \& domestiquer'. 
capable of violent effects, including death, not unlike the consequences anticipated for Christendom from Turkish invasion. In Adrien-Thomas Perdou de Subligny's La fausse Clélie (1671), a character hoarded opium to commit suicide, while in the racy novel Les amans malheureux (1703), the drug was used twice to incapacitate male characters so they could be murdered.

During these very years, other Turkish consumption practices seemed increasingly attractive to Europeans, especially the French. Both coffee and sherbet were enthusiastically embraced in the closing decades of the seventeenth century. While sherbet was almost forgotten by around 1700, however, coffee migrated into French daily life, even becoming identified with Frenchness after colonial commerce geared up in the $1720 \mathrm{~s}^{23}$ The attraction of coffee has been attributed to the capacity it afforded the French elite for staging Orientalism at home: it was part of a whole package of luxury material practices, including Chinese and Japanese porcelain, opulent silk fabrics, and Turkey carpets, increasingly embraced by Europeans as the Ottoman military threat receded. ${ }^{24}$ Coffee was also embraced as a drink of sobriety and health, its symbolism centred upon discussions of Muslim abstinence from wine. Alongside the 'drunken Turk', late seventeenth-century authors thus set the 'sober Turk'. Turkish drugs thus epitomized in miniature French ambivalence over Ottoman habits and politeness, in decades when French overseas efforts were aimed, turn by turn, at establishing French trade with the Ottoman empire, or else at reducing French dependency upon it as a source of the Eastern luxury goods increasingly consumed at home. ${ }^{25}$

Opium was widely consumed all over France, certainly more so than coffee in the 1660s, and perhaps even as late as the early 1680s. Itinerant merchants of opium-containing remedies travelled Europe selling their drugs in towns and at seasonal fairs. In France, these travelling healers were known as operators, or more pejoratively 'charlatans'. ${ }^{26}$ Operators appear to have been cosmopolitan figures, with itineraries which took them from town to town. ${ }^{27}$ In the early decades of Louis XIV's reign, they formed loose-knit kinship networks,

\footnotetext{
${ }^{23}$ Spary, Eating the Enlightenment, ch. 2. Ottoman trade and consumption of opium and sherbet have attracted little scholarly interest for the early modern period; however, opium remained an important export good into the nineteenth century: see A. Üner Tyrgay, 'The nineteenth-century Golden Triangle: Chinese consumption, Ottoman production, and the American connection, part 2', International Journal of Turkish Studies, 3 (1984), pp. 65-91. On coffee consumption within the Ottoman empire, see especially Ralph S. Hattox, Coffee and coffeehouses: the origins of a social beverage in the medieval Near East (Seattle, WA, 1991).

${ }^{24}$ Ina Baghdiantz-McCabe, Orientalism in early modern France: Eurasian trade, exoticism, and the ancien régime (Oxford, 2008); Julia Landweber, “This marvelous bean": adopting coffee into Old Regime French culture and diet', French Historical Studies, 38 (2015), pp. 193-223.

${ }^{25}$ See especially Alexander Bevilaqua and Helen Pfeifer, 'Turquerie: culture in motion, 16501750', Past \& Present, 221 (2013), pp. 75-118; Spary, Eating the Enlightenment, ch. 2.

${ }^{26}$ On theatrical healing, see M. A. Katritzky, Healing, performance and ceremony in the writings of three early modern physicians: Hippolytus Guarinonius and the brothers Felix and Thomas Platter (Farnham, 2012); David Gentilcore, Medical charlatanism in early modern Italy (Oxford, 2006).

${ }^{27}$ Sandro Bassetti, L'orviétan. Medicina universale 1504-1828 (Cologno Monzese, 2011); Claude-Stephen Le Paulmier, L'orviétan. Histoire d'une famille de charlatans du Pont-Neuf aux XVIIe et XVIIIe siècles (Paris, 1893).
} 
whose members offered entertainment coupled with healing services. Such performers could recruit royal patronage; in the 1660s, several were both wellpaid court entertainers and well-known healers. Common characterizations of them as humble street performers or popular healers reflect repeated attacks by corporate medical practitioners over a long period. Since few operators published anything longer than advertising brochures - most of which are lost-historians have depended upon these pejorative images peddled by their medical rivals. But in reality, operators seem to have commanded a similar clientele to licensed physicians; their main distinction lay in their itinerancy and their use of spectacle and print for self-promotion. The legitimacy of operators seems to have been high in the eyes of the French crown at midcentury, when the title of 'royal operator' was bestowed upon large numbers of healers. ${ }^{28}$ It was precisely operators' successes, not their incapacity, that would bring the wrath of faculty physicians down upon their heads.

Definitions of the term show that, before 1700, the title was widely associated with sellers of exotic drugs, particularly opium compounds, whether chemists, dentists, or surgeons. According to one dictionary published in 1680 , an operator was a 'kind of chemical physician who usually sells or offers for sale balm and other kinds of drugs on a stage in town squares', exemplified with the phrase 'A good operator. ${ }^{29}$ Over the next decade, the public credibility of drugs operators appears to have declined. Antoine Furetière's dictionary of 1690 mentioned surgical operators first, but then added a second entry under the heading 'Operateur': 'also used of an empiric or charlatan who sells drugs and remedies in public and at the theatre, who announces his location and science by distributing advertisements and leaflets. People calling themselves royal operators and distillers ought not to be trusted. ${ }^{30}$ The title became less desirable over time, but the figure of the operator remained a household name until the end of the eighteenth century, by which point the term principally designated individuals who performed surgical operations - tooth-pulling, hernia repair, cutting for cataracts or the stone, and tumour removal.

In the seventeenth century, the core of the operators' pharmaceutical arsenal was the famous drug theriac. This celebrated antidote was supposedly invented by Andromachus, physician to Emperor Nero, and thus represented an ancient imperial medical world. Many operators sold one of countless

\footnotetext{
${ }^{28}$ Based on the author's unpublished research using the Minutier Central, Paris.

${ }^{29}$ César-Pierre Richelet, Dictionnaire françois, contenant les mots et les choses, plusieurs nouvelles remarques sur la langue françoise (2 vols., Geneva, 1680), II, p. 92: 'Sorte de Médecin chimique qui ordinairement vend, ou fait vendre du baume \& autres sortes de drogues sur un téâtre dans les places publiques des villes'; 'Un bon operateur'. For another example, see Philibert Monet, Invantaire des devs langves, françoise, et latine: assorti des plvs vtiles cvriositez de l'un, \& de l'autre idiome (Lyon, 1635), p. 612.

${ }^{30}$ Antoine Furetière, Dictionnaire universel, contenant generalement tous les mots françois tant vieux que modernes, et les termes de toutes les sciences \& les arts ( 3 vols., The Hague and Rotterdam, 1690-1), III, s.v. 'Operateur': 'se dit aussi d'un Empyrique, d'un Charlatan qui vend ses drogues, \& ses remedes en public \& sur le theatre, qui annonce son logis \& sa science par des affiches \& des billets qu'il distribuë. Il ne se faut pas fier à ces gens qui se disent Operateurs \& Distillateurs du Roi.'
} 
variants of theriac known, by the early seventeenth century, as 'orvietan', after the supposed birthplace of the recipe's inventor. Orvietan exemplified early modern polypharmacy; recipes for it included around forty to seventy different ingredients, mostly non-European. The drug was a portmanteau, containing several opium compounds besides theriac. Principally manufactured in Venice, and distributed across the Galenic medical world, from Europe in the West to China in the East, theriac largely derived its power from two ingredients widely held to be poisonous: opium and viper flesh. ${ }^{31}$ Their inclusion reflected a long-standing view, mentioned in Galen, that all poisonous natural bodies on earth contained their own antidote, and that a skilful practitioner could extract an antidote from the matter of the poison itself. ${ }^{32}$ A 1667 Augustinian emblem book captures this in theological terms, figuring the Eucharist - the substance which cost Christ his life, yet which when consumed supplies the antidote to $\sin$ - as a double-headed snake: 'Though I breathe a cruel venom, I offer you a benign remedy' (Figure 1). ${ }^{33}$

It was this very operation at which operators excelled: extracting the antidotary power from the substance of a toxic plant or animal. One reason for investing so much time and expense in manufacturing complex opiumcontaining compound drugs like orvietan and theriac was that certain techniques for processing opium and viper flesh were held to temper the toxicity of these poisonous natural substances. ${ }^{34}$ Operators were closely associated with the manipulation of poisonous animals. According to a biography of one of the most famous operators, Gilles Bary, published in 1704, his healing performances alternated with entertainments such as tightrope-walking and short plays. Onstage with just one or two assistants, he would

entertain his auditorium with the virtue of his remedies and the marvellous effects they had produced all over Europe, and which they had just recently been producing in Italy. He spoke about everything, exaggerating the strength of his antidote and its infallibility against poisons and the stings or bites of venomous beasts, holding toads, salamanders, asps and vipers in his hands, with which he would play as if they were unable to harm him, or as if they knew to respect his person and his remedies. ${ }^{35}$

\footnotetext{
${ }^{31}$ See, e.g., Christiane Nockels Fabbri, 'Treating medieval plague: the wonderful virtues of theriac', Early Science and Medicine, 12 (2007), pp. 247-83; Carla Nappi, 'Bolatu's pharmacy: theriac in early modern China', Early Science and Medicine, 14 (2009), pp. 737-64; Guy Attewell, 'Interweaving substance trajectories: tiryaq, circulation and therapeutic transformation in the nineteenth century', in Anne Digby, Waltraud Ernst, and Projit B. Mukharji, eds., Crossing colonial historiographies: histories of colonial and indigenous medicines in transnational perspective (Cambridge, 2010), pp. 1-20.

${ }^{32}$ Alisha Rankin, 'On anecdote and antidotes: poison trials in sixteenth-century Europe', Bulletin of the History of Medicine, 91 (2017), pp. 274-302; Pugliano, 'Pharmacy, testing, and the language of truth'.

${ }^{33}$ Augustin Chesneau, Emblemes sacrez svr le tres-saint et tres-adorable sacrement de l'Evcharistie (Paris, 1667), emblem 72.

${ }^{34}$ Charas, Histoire natvrelle, pp. 295-7; Bernier, Essais de medecine, p. cii.

35 [Bellanger Desfrenaux,] Voyage de Guibray (Paris?, 1704), pp. 150-1: 'entretenir son auditoire de la vertu de ses remedes, \& des effets merveilleux qu'ils avoient produits par toute l'Europe, \& qu'ils venoient encore tout nouvellement de produire en Italie. Il parloit sur tout, avec exageration de la force de son Antidote, \& de son infaillibilité contre les poisons, \& contre les piqures ou morsures de
} 


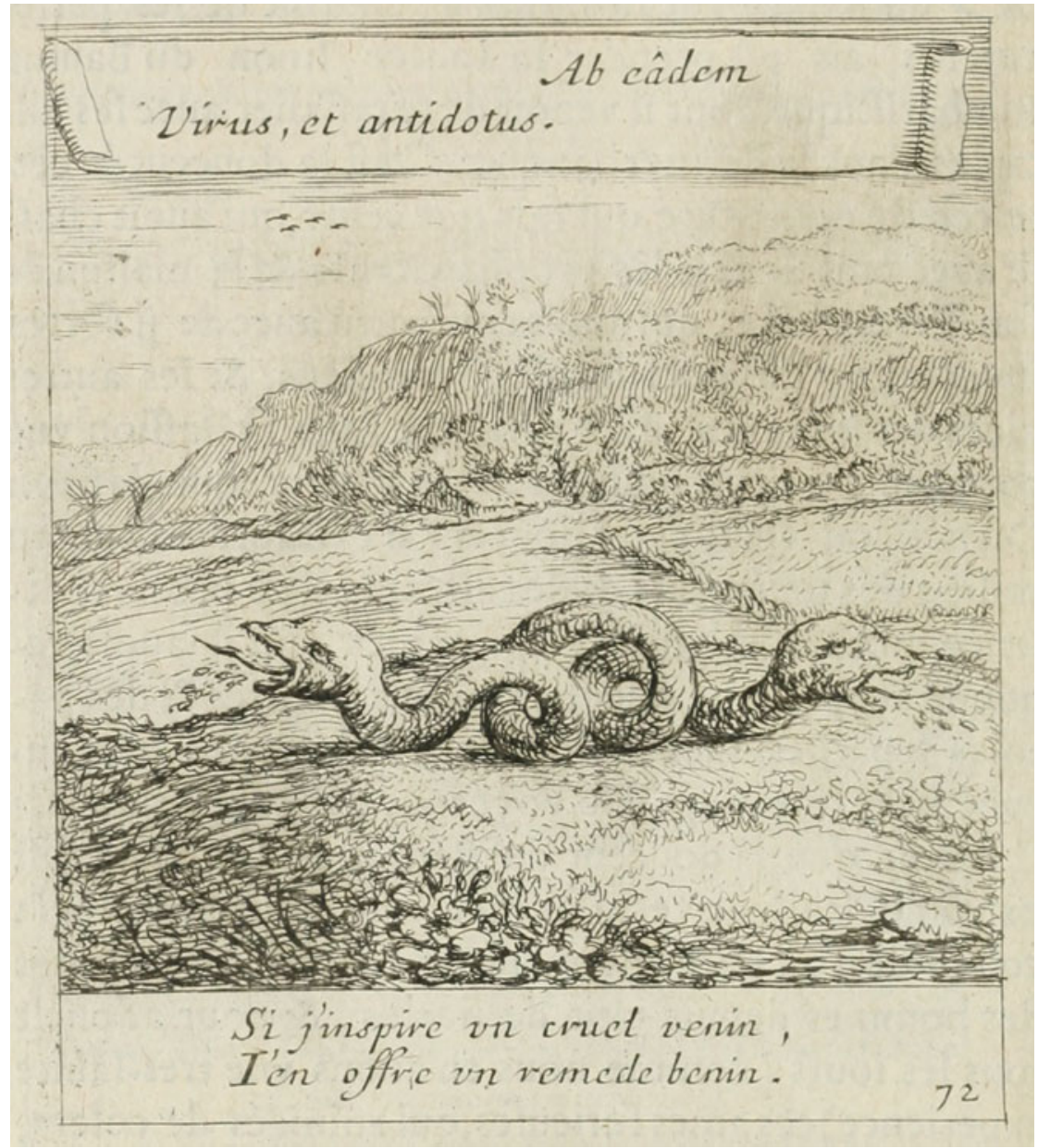

Figure I. Chesneau, Emblemes sacrez, p. 146, emblem 72: 'Le double Marcheur, qui jettant d'vne de ses testes le venin, en donne l'antidote de l'autre.' The two captions, 'Ab eâdem / Virus, et antidotus' and 'Si j'inspire vn cruel venin, / l'en offre vn remede benin', both reference an ancient claim that the same natural body that produced a poison also contained its antidote.

Source: Courtesy of HathiTrust. Online at https://babel.hathitrust.org/cgi/pt?id=gri.ark://3960/t7jq lbp5t\&view= lup\&seq $=162$.

Partly through such adroit deployment of their own bodies as sites of proof, Bary and other operators were successful in enlisting the support of local authorities and princes around Europe. The operators were the most accomplished and bestknown representatives of a particular theatrical style of healing for much of the seventeenth century, and their practice centred upon poisons.

bestes venimeuses, tenant entre ses mains des crapaux, des mourons, des aspics \& des viperes, dont il se joüoit, comme s'ils n'avoient pas pû lui faire de mal, ou comme s'ils avoient sçu respecter sa personne \& ses remedes.' 
It is no coincidence that vipers also loomed large in Charas's selfpresentation. An engraved portrait showing a viper adjacent to his bare hand, shown in Figure 2, effectively places his own embodied experimental skill on a par with that possessed by operators. Even the name of his shop in Paris was the 'Golden Vipers' ${ }^{36}$ Charas is perhaps best remembered within the history of medicine for being on the losing side of a controversy over the toxicity of viper venom in the early 1660s, with the gentlemanly Bolognese physician Francesco Redi. ${ }^{37}$ Few historians, however, have linked Charas's attention to vipers either to his need to compete within the medical marketplace, or to his involvement in contemporary debates on the nature and importance of the passions. So far from failing to comprehend Redi's claim that the venom of vipers resided behind their fangs, as some have suggested, Charas's assertions concerning the efficacy of his theriac in fact depended upon his claim to be able to convert the poisonous viper into a benign medicament: he argued that toxicity, in this case, was the consequence of the viper's bad humours which, aroused by the animal's irritated state, were injected into its victim with the bite. As Catellani and Console rightly recognize, this controversy is more properly described as reflecting 'a transition from an animate view of the world to one where empirical methods do not appear to need to invoke "spirits". ${ }^{38}$ Charas's reiterated descriptions of his prowess in swallowing opium with impunity similarly proclaimed his own body as at once a site of performance and of proof. He cast himself in the same terms as the operators themselves: as someone wielding the power to extract the essence of poisonous natural things like opium or vipers and convert them into healing power instead. Charas's own embodiment, in short, could not be extricated from his account of the relationship between cause and effect in trialling the efficacy of drugs. ${ }^{39}$

It is clear that contemporaries understood very well the perils that this set of claims posed to defending scholarly credibility. After Charas fled France in the 1680s, persecuted by the crown for his faith, the physician Jean Bernier jeered that

If orvietan had stayed in Italy, the theriac that [Charas] has made reputable, and which he made fashionable in the name of his country... wouldn't have challenged Andromachus's great theriac, and wouldn't have made its author move from the theatre into the Paris bourgeoisie, if he hadn't gone over the mountains with it. ${ }^{40}$

\footnotetext{
${ }^{36}$ Phisalix, 'Moyse Charas'.

${ }^{37}$ Felix, 'Moyse Charas'; most recently, see Jutta Schickore, About method: experimenters, snake venom, and the history of writing scientifically (Chicago, IL, 2017), ch. 3.

${ }^{38}$ Patrizia Catellani and Renzo Console, 'Moyse Charas, Francesco Redi, the viper and the Royal Society of London', Pharmaceutical Historian, 34 (2004), pp. 2-10.

${ }^{39}$ On the disembodiment of natural knowledge entailed by the new natural philosophy, see especially Christopher Lawrence and Steven Shapin, eds., Science incarnate: historical embodiments of natural knowledge (Chicago, IL, 1998).

${ }^{40}$ Bernier, Essais de medecine, p. 472: 'Si l'Orvietan fut demeuré en Italie, la Theriaque qu'il a mise en reputation, \& qui l'avoit mis luy-même en vogue sous le nom de sa Patrie ... n'auroit pas bravé la grande Theriaque d'Andromachus, \& n'auroit pas fait passer son Auteur du Theâtre dans la Bourgeoisie de Paris, s'il n'avoit passé les Monts avec elle.'
} 


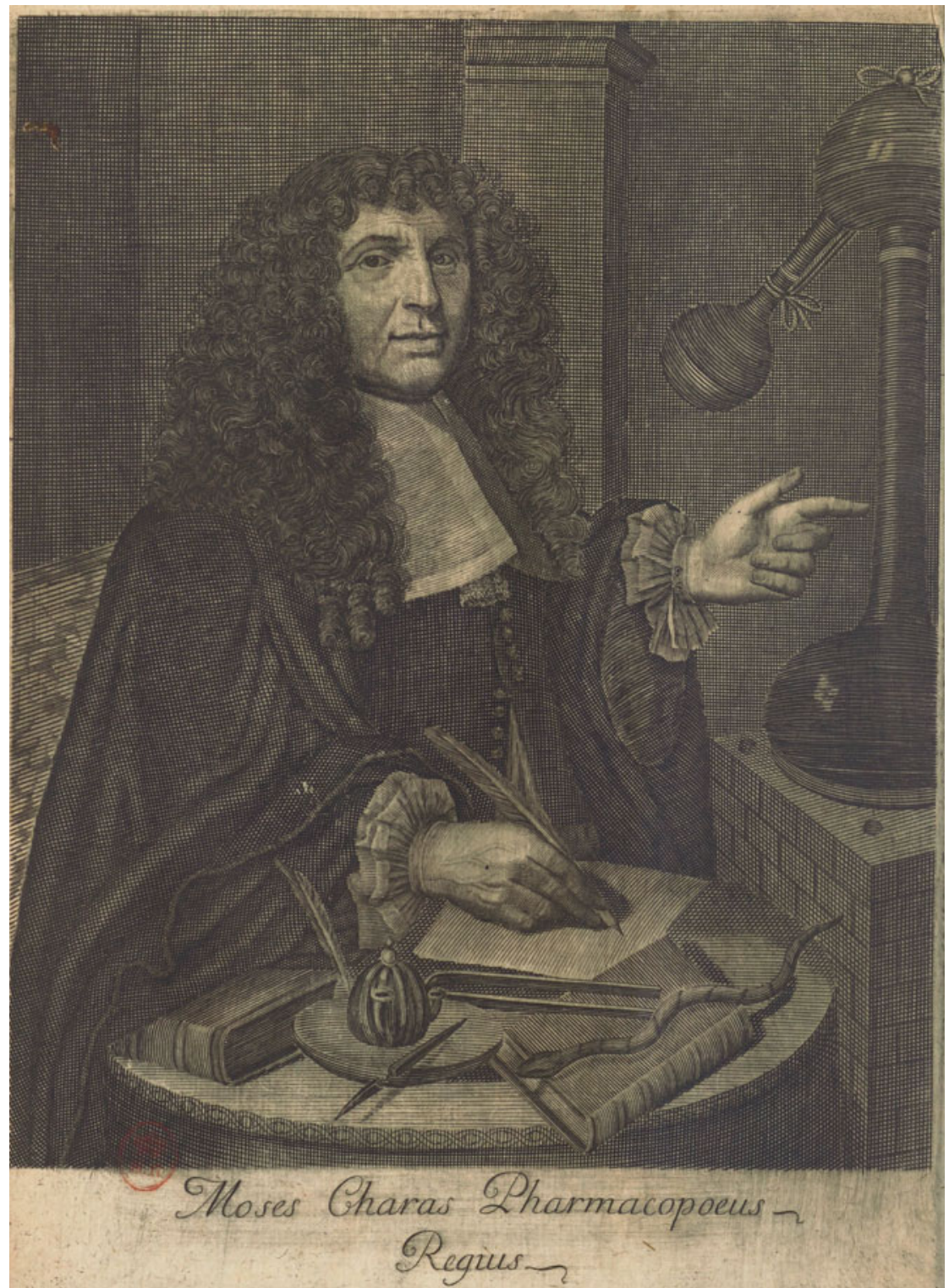

Figure 2. Moyse Charas, Pharmacopoea regia galenica, gallice ab authore conscripta, jam vero latina lingua donata (3 vols., Geneva, 1684), I, opp. p. I: 'Moses Charas Pharmacopoeus Regius'. Although this appears at first glance to be a typical scholarly portrait of the man of letters among his books, cabinet, and alembic, the addition of a small viper flags the connection between Charas and antidotary culture. Source: (c) Bibliothèque nationale de France. 
Charas was perceived to use the same tactics as the operators for attracting official attention - dramatic devices such as auto-experimentation, staged displays of corporeal mastery over nature, immunity from poisons, exotic drugs, and classical allusions. Also like the operators, he seemed not to separate questions of consumption, publicity, and profit from the work of healing and the credibility of natural knowledge claims. The genre to which his experimental activities belonged was spectacular, because spectacle remained a vital asset in attracting patrons, rich or poor; and in the 1660s, it was still the operators who defined what it meant to conduct a public trial with the body. As Mario Biagioli has argued for the case of Galileo, early modern experiment was a rhetorical strategy. ${ }^{41}$ Experimentation was often performed in the context of competition for commercial monopolies over the production and sale of new commodities, and attempts to secure patronage from courtiers. Thus, as Martha Baldwin observes, during these decades an experiment was not necessarily carried out to settle a knowledge controversy. It is precisely this circumstance that underscores the need for historians to avoid viewing early modern experiments anachronistically. ${ }^{42}$

III

On their circuits from town to town, operators courted urban and central authorities such as magistrates, city police, and monarchs, seeking official permission to perform and manufacture their remedies in public. The very same kinds of authorities presided over a series of public demonstrations of the manufacture of theriac by Charas in 1660s Paris, and other apothecaries after him: Mathieu-François Geoffroy, Simon Boulduc, Antoine Josson, and Henry Rouvière. Their performances were carefully staged, choreographed, and publicized. Audiences included magistrates, physicians, 'and all people of distinction, from Paris as well as court, who came in large numbers'. ${ }^{43}$ Another journalist mentioned 'numerous assemblies' attended by 'a sizeable number of people of distinguished merit and consummate science in medicine and pharmacy'. ${ }^{44}$ For city apothecaries, these making ceremonies - which were part of a long apothecarial tradition, as the work of Watson, Nockels

\footnotetext{
${ }^{41}$ Mario Biagioli, Galileo, courtier: the practice of science in the culture of absolutism (Chicago, IL, 1993). See also Steven Shapin, 'The house of experiment in seventeenth-century England', Isis, 79 (1988), pp. 373-404.

${ }^{42}$ Martha Baldwin, 'The snakestone experiments: an early modern medical debate', Isis, 86 (1995), pp. 394-418; also Steven Shapin and Simon Schaffer, Leviathan and the air-pump: Hobbes, Boyle, and the experimental life (Princeton, NJ, 1985); Koen Vermeir, "The "physical prophet" and the powers of the imagination, part I: a case-study on prophecy, vapours and the imagination (1685-1710)', Studies in History and Philosophy of Biological and Biomedical Sciences, 35 (2004), pp. 561-91.

${ }^{43}$ Mercure Galant, Oct. 1704, p. 92: '\& toutes les personnes de distinction, tant de Paris que de la Cour, qui y vinrent en grand nombre'. On earlier theriac production in Paris, see Nappi, 'Bolatu's pharmacy', p. 750.

${ }^{44}$ Anon., Lettre adressée à Messieurs les doyen et docteurs professeurs en pharmacie de la Faculté de Medecine à Paris (Paris, 1703), p. 5: 'un assez grand nombre de personnes d'un mérite distingué \& d'une science consommée dans la Medecine \& dans la Pharmacie'; Mercure Galant, Oct. 1702, pp. 23-54; Mercure Galant, Oct. 1704, pp. 63-92.
} 
Fabbri, and Pugliano has shown - served the double purpose of capturing the trade in opiates, in particular the highly lucrative theriac, and asserting their own pre-eminence over knowledge and standards of manufacture, against which the orvietanists' foreignness, lack of humanist erudition, and paucity of connections with scholarly circles could be framed as questionable. 'Orvietan and all the other counter-poisons which are no more than an imitation of theriac, or rather disguised theriac, must yield to it in virtue and excellence. ${ }^{45}$

In reproducing an ancient drug such as theriac, these experimenters might be classed within a positivist history of medicine as reactionaries rather than innovators. ${ }^{46}$ But such public displays had a very different significance for contemporaries. They showed, in good Colbertian fashion, that the French could break their dependency upon an exotic drug normally imported from the Venetian Republic. As one journalist put it, "Rome and Venice will have to admit, after so many widely known and public experiments, that France can do without all her neighbours. ${ }^{47}$ For the apothecaries, these experiments also stood for the capacity to wrest theriac back from the itinerant operators' networks, and preserve it as a drug which was better understood and manufactured by licensed, static urban healers attached to the crown or the guild than by mobile foreigners: 'in this way, ill-intentioned people can be prevented from carrying out a dishonourable public trade in all the kingdom's fairs, where the price at which it is sold is enough to indicate its poor composition and their crookery'. ${ }^{48}$

Operators were by no means the only competitors whom apothecaries faced in the opium market. Others too were aware how profitable a 'domesticated' form of opium, made safe for European bodies, might be in the French medical marketplace. ${ }^{49}$ The spagyric chemist and royal physician Nicolas de Locques was also experimenting on opium in Paris during these same years, endeavouring to correct the adverse effects of opium by chemical means: exalting it, stripping it of its earthy properties, and converting its essence or sulphur into a salesworthy Paracelsian 'divine Laudanum'.50 Charas suggested that

\footnotetext{
${ }^{45}$ Journal des Sçavans, 28 Feb. 1684, p. 63: 'l'Orvietan \& tous les autres contre-poisons qui ne sont qu'une imitation de la Theriaque, ou plustost des Theriaques déguisées, luy doivent ceder en vertu \& en excellence'. On the longer history of theriac, see especially Nockels Fabbri, 'Treating medieval plague'; Pugliano, 'Pharmacy, testing, and the language of truth'; Gilbert Watson, Theriac and mithridatium: a study in therapeutics (London, 1966).

${ }^{46}$ In the words of J. P. Griffin, for example: 'Perhaps in the final analysis, the contribution of Mithridatium and theriac to modern medicine was that concerns about their quality stimulated the earliest concepts of medicines regulation' ('Venetian treacle and the foundation of medicines regulation', British Journal of Clinical Pharmacology, 58 (2004), pp. 317-25, at p. 325).

${ }^{47}$ Mercure Galant, Oct. 1704, p. 64: 'Rome \& Venise doivent avoüer aprés tant d'Experiences si connuës \& si publiques, que la France peut se passer de tous ses voisins.'

${ }^{48}$ Mercure Galant, Oct. 1704, pp. 82-83: 'par ce moyen on pourroit empecher les mal-intentionnez d'en faire un commerce infame \& public dans toutes les Foires du Royaume, où le prix qu'elle y est venduë suffit pour en faire connoistre la mauvaise composition \& leur friponnerie'.

${ }^{49}$ Until at least the 1820s, French chemists continued to view an extract of opium as an antidote to its toxic effects (see Richard Davenport-Hines, The pursuit of oblivion: a social history of drugs (London, 2002), pp. 47-8).

${ }^{50}$ Nicolas de Locques, Rvdimens de la philosophie natvrelle tovchant le systeme $d v$ corps mixte (Paris, 1665-8), s.v. 'Laudanum de Paracelse' (part II, pp. 51-6).
} 
experimenters like Locques had their 'reasoning ... shaped by the soporific vapours they had just made the Opium produce ... which they had inhaled beyond reason, ${ }^{51}$

Charas's auto-experimentation, with which we began, may thus be interpreted in the light of his own efforts to commodify opium in a crowded marketplace. He regularly emphasized that his own product, opium extract, contained the pure virtue of the drug, yet was safe to use even in high doses; the paper he presented to his fellow academicians in 1696, for example, contains several such 'product placements'. Yet, interestingly, historians have largely overlooked the extent to which Charas's involvement in the scholarly world was continuous with his commercial activities: he is one of the few figures from the medical marketplace of these decades to have retained at least some credibility as an academic chemist. ${ }^{52}$ He recruited learned standing in part by rehabilitating theriac as a topic worthy of scholarly interest, publishing a treatise which explored in detail the natural history of its principal ingredients, each carefully researched in humanist style.

Among those ingredients, of course, opium held a prominent place, one which it retained in subsequent attempts to manufacture theriac in Paris. The exact plant which produced Levantine opium remained in doubt well into the eighteenth century, despite attempts by rival groups of apothecaries to invoke botanical expertise in order to identify the 'true' opium of commerce. Many a commentator would claim as fact that 'the Turks hold the true opium in such high regard that they do not allow it to be transported to us', explaining why the drug known in France failed to produce the same effects as in the Ottoman empire. The uncertain geopolitics of the opium trade, and the lack of direct access to sites of cultivation and processing by French merchants, made it impossible to settle controversies in Paris about what 'true opium' should look like and who possessed it. ${ }^{53}$ In more than one way, opium resisted adaptation to French bodies, scientific knowledge, or medical processing.

\section{IV}

Opium's links to the Ottoman empire meant that it was widely seen in late seventeenth-century French literate culture as a drug denoting otherness and wildness, which, perhaps, could not be domesticated at all, despite the attempts by medical entrepreneurs alert to the opportunities offered by the expanding medical marketplace (only some of which have found mention in this article). This was not for lack of trying. A whole industry within the

\footnotetext{
${ }^{51}$ Moyse Charas, Theriaqve d'Andromachvs. Dispensee et achevee publiquement à Paris par Moyse Charas (Paris, 1668), 82: 'raisonnement ... formé par les vapeurs soporiferes qu'ils venoient de faire sortir de l'Opium ... qu'ils avoient humé plus abondamment que de raison'; Locques, Rvdimens.

52 See, e.g., Alice Stroup, A company of scientists: botany, patronage and community at the seventeenthcentury Parisian Royal Academy of Sciences (Berkeley, CA, 1990), pp. 20-1, 172-3, 209; David J. Sturdy, Science and social status: the members of the Académie des Sciences, 1666-1750 (Woodbridge, 1995), pp. 254-7; Allen G. Debus, The French Paracelsians: the chemical challenge to medical and scientific tradition in early modern France (Cambridge, 1992), pp. 130-1, 152-4.

${ }^{53}$ Charles Bagard, Discours sur l'histoire de la thériaque (Nancy, 1725), p. 17.
} 
medical marketplace sought to make available and commodify opium's perceived virtues of tranquillity, fortification, or analgesia, while stripping it of its capacity to produce drunkenness, incapacitation, nausea, frenzy, or death. That is to say, processors of opium claimed to prevent its European consumers from turning into Nicolay's image of the Turk. Such operations upon the drug were implicitly framed within a debate around (European) reason as the proper route to mastery of exotic material nature.

Yet controversies over how to process and use opium safely remained unresolved into the eighteenth century, in spite of the optimistic remarks of authors and auto-experimenters like Charas or Hecquet. Charas's own experimental practice in fact contributed to this state of affairs. He continued to deploy his opium-eating and viper-handling activities far more as a way to gain credit through displays of corporeal and intellectual exceptionalism than as a means of producing standardized, communal knowledge of the kind approved by the Paris Academy of Sciences. Furthermore, as his contemporaries occasionally spotted, he was hijacking the project of scholarly knowledge for commercial ends. What survived of his enterprise was thus not so much a better reputation for opium, but far more a revival of a tradition of public theriac-making among Parisian apothecaries. I have suggested here that this served two main purposes: the first being to divert the attention and patronage of authorities from operators to apothecaries, and the second being to establish intellectual respectability for apothecaries as rivals of the ancients and servants of the public.

Considering Charas's activities in this light, we can see that his autoexperimentation with opium and his careful self-accounting had several interconnecting goals. In a broader sense, his activities have important implications for how we might write the history of experimentation in seventeenth-century France. For the principal definition of the word experimenter in the Dictionnaire de l'Académie françoise of 1694 was 'to trial a remedy, receipt [or] secret by experience', and the main example concerned plants: 'if you doubt the virtue of that plant, you may experiment with it. ${ }^{54}$ One has to ask why no history of the 'scientific revolution' in France has taken seriously, or even noted, the fact that the first and principal meaning of 'to experiment' in the late seventeenth century was 'to trial the efficacy of drugs'. Conversely, the narrow understanding of that efficacy as resting on controlled trials in purified spaces that is often invoked in the history of medicine needs to give way to broader studies that explore all the resources marshalled to produce both cure and proof in a given culture, as well as the ways in which contemporaries responded to these evidential gambits. ${ }^{55}$

\footnotetext{
${ }^{54}$ Le dictionnaire de l'Académie françoise: dedié au roy (4 vols., Paris, 1694), I, p. 418: 'Esprouver par experience un remede, une recette, un secret ... si vous doutez de la vertu de cette plante, vous la pouvez experimenter.' This exhortation to auto-experiment may be contrasted with a definition some decades later in Dictionnaire universel françois \& latin, II, p. 1583: 'On experimente les remedes sur des personnes de peu d'importance'. For a more conventional interpretation of the term, see Claire Salomon-Bayet, L'institution de la science et l'expérience du vivant. Méthode et expérience à l'Académie royale des sciences, 1666-1793 (Paris, 1978), e.g. p. 165.

${ }^{55}$ Stolberg, 'Der gesunde Leib', pp. 44-8, shows that early modern European humoral medicine foregrounded contamination and the expulsion of poisons from the body.
} 
The aim in this article has not been to retell the history of opiumcontaining drugs in Europe from a new perspective, but rather to explore the work that a particular substance did in a particular culture in mediating and transforming social, geopolitical, and corporeal states. It is precisely this historical agency which is lost if the effects of the consumed substance upon bodies are assumed a priori by the historian. Opium could have a continuous history within French medical tradition, and yet be mobilized to serve new purposes by different historical actors in response to chronologically specific geopolitical, commercial, and epistemological circumstances. It is for these reasons that opium may be characterized as a drug of alterity in the reign of Louis XIV.

Acknowledgements. This article forms part of Intoxicants and early modern European globalization: spaces, practices, material culture, a special issue resulting from a workshop series, held in 2017 at the Victoria and Albert Museum and in 2018 at the Beinecke Library, Yale University. My thanks go to participants at the first of these two events in particular, as also to Justin Rivest, Samir Boumediene, and Laia Portet i Codina, the team of the project 'Selling the exotic in Paris and Versailles'.

Funding Statement. The workshop series at the Victoria and Albert Museum was funded by the ESRC 'Intoxicants \& Early Modernity Project'. Financial support from the Leverhulme Trust is gratefully acknowledged.

Cite this article: Spary EC (2022). Opium, Experimentation, and Alterity in France. The Historical Journal 65, 49-67. https://doi.org/10.1017/S0018246X21000297 